\title{
Method Validation for the Trace Analysis of Geosmin and 2-Methylisoborneol in Water by "Salt-Free" Purge-and-Trap Sampling/GC-MS, Using the Eclipse 4660 Sample Concentrator
}

\section{Thavrin Manickum* and Wilson John}

Scientific Services Laboratories, Engineering \& Scientific Services, Head Office, Level 3, Umgeni Water, 310 Burger Street, Pietermaritzburg 3201, KwaZulu-Natal, South Africa

\begin{abstract}
The Eclipse 4660 purge-and trap sample concentrator, coupled to a gas chromatograph-mass spectrometer, was fully validated for trace analysis of the taste-odorants geosmin (GSM) and 2-methylisoborneol (2-MIB) in the absence of salt or methanol. The procedure involved purging a $25 \mathrm{~mL}$ sample volume, at $80^{\circ} \mathrm{C}$, for 11 min. Quantitation was done by separation on an HP 5-MS capillary column $(30 \mathrm{~m} \times 0.25 \mathrm{~mm} \times 0.25 \mu \mathrm{m})$, followed by mass spectrometric detection in the selected ion monitoring (SIM) mode. The method was found to be linear $\left(r^{2} \geq 0.995\right)$ over the calibration range $0-100 \mathrm{ng} / \mathrm{L}$ for both target analytes. The overall accuracy, determined by recovery, was $104.21 \%$ \pm 19.46 (mean \pm SD, range $=65.29-143.13 \%)$ for $2-\mathrm{MIB}$, and $85.24 \% \pm 8.28($ mean $\pm \mathrm{SD}$, range $=68.66-101.82 \%)$ for GSM. The within-day precision averaged $7.97 \%$ for 2-MIB, and $8.77 \%$ for GSM. The day-to-day precision was $20.96 \%$ for 2-MIB, and $7.52 \%$ for GSM. The limit of quantitation (LOQ) was $6 \mathrm{ng} / \mathrm{L}$ and $5 \mathrm{ng} / \mathrm{L}$ for 2-MIB and GSM; the limit of detection (LOD) was $5 \mathrm{ng} / \mathrm{L}$ and $4 \mathrm{ng} / \mathrm{L}$ for 2-MIB and GSM respectively. Earlier findings regarding the dehydration of 2-MIB to 2-methyl-2-bornene (2-M-2-B) were confirmed. The average amount of 2-M-2-B formed was $27 \%$ (range: $15-50 \%$ ), with RSD $=33.26 \%$. There is evidence of dehydration of 2-MIB to $2-\mathrm{M}-2-\mathrm{B}$ at sample purge temperature of $40^{\circ} \mathrm{C}$ and higher. The poor day-to-day precision for 2-MIB has been proposed to be due to the inconsistent amount of 2-M-2-B formed. A minimum sample purge temperature of $30^{\circ} \mathrm{C}$ is required to purge $2-\mathrm{MIB}$ and GSM from water, which can be detected by GC/MS under the purge-and-trap conditions at a concentration of $100 \mathrm{ng} / \mathrm{L}$. The developed method was found to be sensitive, accurate, precise and reproducible for trace analysis of geosmin in water matrices.
\end{abstract}

Key words: Eclipse sample concentrator; Purge-and-trap; Saltfree extraction; Geosmin; Gas chromatography-mass spectrometry; 2-MIB; Dehydration

\section{Introduction}

Geosmin (GSM) and 2-methylisoborneol (2-MIB) are two of the most commonly occurring unpleasant taste-odor causing compounds in drinking water [1]. Because of their low odor detection threshold [24], many drinking water testing laboratories require detection limits of 1-3 $\mathrm{ng} / \mathrm{L}$ and quantitation at $5 \mathrm{ng} / \mathrm{L}$ concentration.

Reported extraction techniques from water matrices include Solvent Extraction (SE) (liquid-liquid) [5-9] and closed loop stripping analysis [10]. However, the latter techniques are all time-consuming and labor-intensive [11,12].

Membrane extraction has improved detection limits [13,14]. Solid phase extraction is also time consuming and is unsuitable for low boiling point odorants [15-17]. Solid Phase Micro Extraction (SPME) is relatively simple, fast, inexpensive, portable and solvent-free. Various reports [18-21] show their excellent analytical utility and applicability to other common taste-odorants as well.

Table 1 summarizes the various extraction techniques for 2-MIB and GSM, coupled to GC-MS detection, and the method performance characteristics. In general, it is obvious that many of the reported techniques tend to focus on sensitivity (limit of detection (LOD)) while other equally important parameters, like day-to-day precision, is largely not reported. Very few of the reported techniques appear to have validated recovery (accuracy) from real sample matrices.

Although excellent sensitivity has been achieved with headspacesolid phase micro extraction $(<1 \mathrm{ng} / \mathrm{L})$, precision data regarding day-to-day variation is largely absent or not provided in most of the published reports. The reported method detection limits for the SPME technique, with Chemical Ionization-Mass Spectrometry-Mass Spectrometry (CI-MS-MS), reported by Wang et al [26] was $0.46 \mathrm{ng} / \mathrm{L}$ for 2-MIB, and $0.20 \mathrm{ng} / \mathrm{L}$ for GSM. Inconsistent recoveries in SPME are often due to factors such as equilibration and extraction times, fiber position (both during extraction and desorption) and condition of the fiber. The choice of a fiber suited to large scale analysis of odorants can be problematic $[11,39,40,41,42]$. Data on the more relevant Limits of Quantitation (LOQ) appear to be lacking as well.

Automated Purge-and-Trap (PT) [43], a solvent-free concentration technique, is a rapid technique for Volatile Organic Compounds (VOC) analysis: extraction, pre-concentration and sample introduction are combined into a single step.

Further comparison of HS-SPME with PT indicates that the former technique has the added variable of partition of the solute into the headspace before sampling of the vapor.

*Corresponding author: Thavrin Manickum, Scientific Services Laboratories Engineering \& Scientific Services, Head Office, Level 3, Umgeni Water, 310 Burge Street, Pietermaritzburg 3201, KwaZulu-Natal, South Africa, Tel. +27 33341 1067; Fax: +27 33341 1501; E-mail: thavrin.manickum@umgeni.co.za

Received March 27, 2012; Accepted May 23, 2012; Published May 30, 2012

Citation: Manickum T, John W (2012) Method Validation for the Trace Analysis of Geosmin and 2-Methylisoborneol in Water by "Salt-Free" Purge-and-Trap Sampling/GC-MS, Using the Eclipse 4660 Sample Concentrator. Hydrol Current Res 3:134. doi:10.4172/2157-7587.1000134

Copyright: (c) 2012 Manickum T, et al. This is an open-access article distributed under the terms of the Creative Commons Attribution License, which permits unrestricted use, distribution, and reproduction in any medium, provided the original author and source are credited. 
A review of the reported purge-trap methods and their performance characteristics has been previously discussed [37]. Fairly minimal validation data were reported by the earlier studies [32,33]. Salemi et al [35] reported use of addition of $25 \%(\mathrm{~m} / \mathrm{v})$ sodium chloride to water samples. The observed LOQ and LOD were 3 and $1 \mathrm{ng} / \mathrm{L}$ for $2-\mathrm{MIB}$, and 7 and $2 \mathrm{ng} / \mathrm{L}$ for GSM, respectively.

Following this report, the technical note by Teledyne Tekmar [36] reported much better LOQ for both 2-MIB $(0.2 \mathrm{ng} / \mathrm{L})$ and GSM $(0.1$ $\mathrm{ng} / \mathrm{L})$, achieved with addition of $10 \%(\mathrm{~m} / \mathrm{v})$ salt to the water sample. The observation that the reported LOQ is lower than the LOD makes the data questionable. The precision data for day-to-day variation is not reported.

Although our recently reported, fully validated purge-trap method [37] achieved a LOQ of $2 \mathrm{ng} / \mathrm{L}$ for both 2- MIB and GSM, the day-today variation was $14 \%$ RSD for both compounds.

More recently, Deng et al. [38], reported the simultaneous determination of 2-MIB and GSM, by purge-and-trap/GC-MS. Their relatively comprehensive validation data shows an overall improvement and an optimized purge-trap method when compared to all previously reported purge-and-trap methods for trace analysis of 2-MIB and GSM. However, the Limits of Quantification (LOQ) are not mentioned.

Salting out of organic compounds by addition of sodium chloride has been used to maximize extraction of organic compounds from water matrices, leading to increased sensitivity. Although sensitivity is generally improved, the addition necessitates an extra step in the sample preparation before sample extraction and analysis. Use of the latter in purge-and-trap instruments can lead to salt build-up, blockage and corrosion of the sample pathway valves, lines, needles and sparge vessel.

With our procurement of the Eclipse purge-and-trap sample concentrator as a backup unit for routine testing, we observed an earlier reported finding [44] that 2-MIB undergoes dehydration to 2-methyl2-bornene (2-M-2-B) under the purge-and-trap conditions [45] during our preliminary method development and optimization. The developed purge-trap method on the Stratum and Eclipse involved purging a 25 $\mathrm{mL}$ water sample at $60^{\circ} \mathrm{C}$ for $30 \mathrm{~min}$. and $80^{\circ} \mathrm{C}$ for $11 \mathrm{~min}$, respectively. Although the overall method parameters used with the Stratum and Eclipse sample concentrators are similar, the dehydration products of 2-MIB, especially 2-M-2-B, was not detected on the Stratum. There are no reports to date of the influence of method parameters on dehydration of 2-MIB. The other reported dehydration product of 2-MIB [44] is 2-methylene-2-bornane (2-MB). The relative presence and concentration of $2-\mathrm{M}-2-\mathrm{B}$, and even $2-\mathrm{MB}$, therefore warrants research during trace analysis of these taste-odorants in water samples.

In the light of the poor day-to-day variation we noted on the Stratum sample concentrator [37], the objective of the present work was to validate the performance of the Eclipse sample concentrator as an alternative extraction technique, coupled to GC-MS, in terms of linearity, selectivity, sensitivity, accuracy and precision for the trace analysis (simultaneous) of these two taste-odorants in water matrices for routine testing of water samples.

We now report our findings regarding the method validation of the test method on the Eclipse sample concentrator at the commonly used sample purge temperature of $80^{\circ} \mathrm{C}$. The effect of sample purge temperatures lower than $80^{\circ} \mathrm{C}$ on the dehydration of $2-\mathrm{MIB}$ and on the overall sensitivity of the test method is also reported on.

\section{Experimental}

\section{Chemicals and consumables}

$( \pm)-$ Geosmin $(100 \mu \mathrm{g} / \mathrm{mL})$ and 2-MIB $(100 \mu \mathrm{g} / \mathrm{mL})$ in methanol, of $99.8 \%$ and $98.3 \%$ purity, were obtained from Capital Lab Supplies CC (South Africa). HPLC grade methanol was obtained from Merck (Darmstadt). Ultrahigh purity helium gas (99.999\%) for GC-MS was obtained from Air Products (South Africa). Water was obtained from a Milli-Q (MQ) (MILLIPORE) water purification system (Millipore, USA). The conductivity was on average $0.054 \mathrm{uS} / \mathrm{cm}$ (range: 0.048 $0.060 \mathrm{u} S / \mathrm{cm})$. The \# 7 Tenax trap was supplied by OI Analytical on commissioning of the equipment.

The purge-trap "narrow bore" liner for purge-and trap sampling, was obtained from Chemetrix Ltd (South Africa); the Supelco split liner for liquid auto sampler injections was obtained from Capital Lab Supplies CC (South Africa).

\section{Standard solutions}

A composite standard of $1 \mathrm{mg} / \mathrm{L}$ of GSM and 2-MIB in methanol was prepared from the separate commercial methanol solutions of Geosmin stock $100 \mu \mathrm{g} / \mathrm{mL}$ and the 2-MIB stock $100 \mu \mathrm{g} / \mathrm{mL}$.

A working composite standard of $1000 \mathrm{ng} / \mathrm{L}$ in MQ was prepared from the composite standard. The stability of these standards has been reported previously [37].

Aqueous calibration standards, of concentration 5, 10, 20, 30, 50 and $100 \mathrm{ng} / \mathrm{L}$ were prepared daily, in MQ water, from the working composite standard. A Milli-Q blank ( $=0 \mathrm{ng} / \mathrm{L}$ ) was used to check for any contamination

A composite, Analytical Quality Control sample of GSM and 2-MIB, at $30 \mathrm{ng} / \mathrm{L}$ concentration in MQ water, was similarly prepared using different batch/lot numbers of the commercial $100 \mu \mathrm{g} / \mathrm{mL}$ methanolic solutions of GSM and 2-MIB.

\section{Samples}

The earlier reported procedure was followed [37]. Grab, potable water samples, collected into 1 or $2 \mathrm{~L}$ glass bottles were used directly. Samples were analyzed immediately on receipt or were stored, without any preservative, at $4^{\circ} \mathrm{C}$ overnight if necessary.

\section{Purge-and-trap method}

The full details are as previously reported [45]. A commercial OI Analytical purge-and-trap sample concentrator (Eclipse, Model 4660) coupled to a OI Analytical 50 Vial Auto sampler (Model 4551-A), was used, which automatically dispensed 5-25 mL aliquots of water sample into a $25 \mathrm{~mL}$ fritted purging device (sparger). A transfer line was connected from the concentrator directly to the carrier gas line on the split/splitless inlet of the GC and was insulated to prevent development of a cold spot. Samples were kept chilled at $4^{\circ} \mathrm{C}$ in the Auto sampler rack, via a Constant Temperature Circulator (CARON, Model 2050), that was connected to the Auto sampler.

After pre-heating the sample $(25 \mathrm{~mL})$ for $1.0 \mathrm{~min}$, target compounds were purged from the aqueous sample, at $80^{\circ} \mathrm{C}$ by the use of helium gas, at a purge flow of $40 \mathrm{~mL} / \mathrm{min}$, and were adsorbed onto a Tenax trap at room temperature. During the purge cycle, the trap temperature was set at $20^{\circ} \mathrm{C}$ and the water management fitting was set at a temperature of $120^{\circ} \mathrm{C}$.

After the adsorption stage, the helium was passed through the trap 
for 3.0 min to remove any water trapped on the sorbent (dry purge). The trap temperature was then pre-heated to $170^{\circ} \mathrm{C}$ (pre-heat step) for 5 $\mathrm{sec}$. The trap temperature was then further raised to $180^{\circ} \mathrm{C}$. The trapped analytes were desorbed from the trap, set at $180^{\circ} \mathrm{C}$, with helium gas for 3 min (desorb stage), and entered the injection port of the GC, via a transfer line, set at $140^{\circ} \mathrm{C}$.

A "wash" cycle for the purge-and-trap extractor and auto sampler, between GC-MS runs, was used for cleaning, and the trap was baked at $200^{\circ} \mathrm{C}$ for $15 \mathrm{~min}$. These processes were adequate to reduce carryover of the technique to a negligible level. Detailed conditions have been previously reported [45].

\section{GC-MS conditions}

The detailed conditions have been previously reported [45]. GCMS Analyses were performed on an Agilent Technologies 7890A GC Systems, equipped with an electronically controlled split/splitless injection port set at $200^{\circ} \mathrm{C}$, a split liner and interfaced to an Agilent Technologies 5975C Inert MSD, in Electron Ionization (EI) mode with Triple-Axis Detector. The septum purge vent of the GC was plugged to prevent further losses of target analytes. The GC separation employed a HP5-MS column of dimensions $30 \mathrm{~m} \times 0.25 \mathrm{~mm} \times 0.25 \mu \mathrm{m}$. Helium was the carrier gas at flow rate of $1.0 \mathrm{~mL} / \mathrm{min}$. The oven was set at $40^{\circ} \mathrm{C}$ $\left(3 \mathrm{~min}\right.$ ) and raised to $160^{\circ} \mathrm{C}$ (held for $2 \mathrm{~min}$.) at $5^{\circ} \mathrm{C} / \mathrm{min}$. The oven temperature was then further raised to a final temperature of $280^{\circ} \mathrm{C}$ (held for $5 \mathrm{~min}$ ) at $20^{\circ} \mathrm{C} / \mathrm{min}$; total run time was $22 \mathrm{~min}$. Electron ionization was performed at $70 \mathrm{eV}$, the source temperature and the $\mathrm{GC}$ interface temperature were both set at $230^{\circ} \mathrm{C}$. The emission current was $34.6 \mu \mathrm{A}$ and the detector voltage was set at the EMV Mode with a Gain Factor of 25 .

For SIM mode, each target compound was monitored, using a dwell time of $100 \mathrm{msec}$ and identified using three ions: $\mathrm{m} / \mathrm{z}$ 95, 107, 108 for 2 -MIB, and 111, 112, 125, for GSM respectively. The retention windows were $8.0-13.0 \mathrm{~min}$ and $13.5-16.0 \mathrm{~min}$., for 2-MIB and GSM, respectively.

\section{Qualitative identification}

Qualitative identification was based on retention time analysis. Mass spectral verification on real water samples was done by comparison of relative abundance values of the quantification and qualification ions to the same values obtained from the standard samples.

\section{Analysis of blanks}

Evaluation of MQ water indicated average values of well below the LOD for both 2-MIB and GSM.

\section{Carry-over evaluation}

An air blank was run after assay of a $100 \mathrm{ng} / \mathrm{L}$ standard solution in MQ water. Signal responses for presence of 2-MIB and GSM were nondetectable or well below the LOD.

\section{Results and Discussion}

\section{Method validation}

Our laboratory testing facility is ISO/IEC 17025 accredited by SANAS (South African National Accreditation System). One of the requirements for such accredited testing laboratories is demonstrated evidence of comprehensive method validation of test methods to prove that an analytical test method is deemed suitable for its intended purpose. We have an internal laboratory procedure [46] for method validation based on published literature [47]. Our internal limits for acceptable linearity, accuracy (recovery) and precision (RSD \%) is generally: $r^{2} \geq 0.995,80-120 \%$ and $10 \%$ for our chemical test methods. These limits apply to the LOQ determination; the LOD is the next lower concentration at which the accuracy is $<80 \%$, and precision (RSD) is $>$ $10 \%$. Exceptions to these limits are permitted in exceptional instances where validation data indicate an inherent aspect of the analytical test method. The method validation parameters (specificity/selectivity, linear range, accuracy, precision, limit of detection and quantitation, scope of analysis) were determined. All results are based on the response for the quantitation ions $\mathrm{m} / \mathrm{z} 95$ for 2-MIB, and m/z 112 for GSM.

Linear range and specificity/selectivity; Calibration standard solutions, at concentrations of 5, 10, 20, 30, 50 and $100 \mathrm{ng} / \mathrm{L}$, were prepared in MQ. The data were fitted to a straight line. Regression analysis showed good linearity. The correlation coefficient $r^{2}$, determined over 10 days, averaged $0.996(\mathrm{SD}=0.004, \mathrm{RSD}=0.41 \%)$ for $2-\mathrm{MIB}$, and $0.998(\mathrm{SD}$ $=0.002, \mathrm{RSD} \%=0.21)$ for GSM respectively, indicating acceptable linearity.

The retention time for 2-MIB and GSM, determined by analysis of calibration standards data, in MQ water over 5 days, averaged 11.991 $\min .(\mathrm{SD}=0.004, \mathrm{RSD}=0.03 \%)$ and $15.186 \mathrm{~min} .(\mathrm{SD}=0.0001, \mathrm{RSD}=$ $0.00068 \%)$ respectively.

Raw water (dam) matrix was spiked with both target analytes at concentrations of $0,5,10,20,30,50$ and $100 \mathrm{ng} / \mathrm{L}$. A plot of spiked analyte concentration versus analyte response afforded the following equations: $r^{2}=0.998$ ( $\mathrm{SD}=0.001$, RSD $=0.10 \%$ ), (averaged over 3 days), for 2-MIB, and $r^{2}=0.993$ (SD $=0.006, \mathrm{RSD}=0.60 \%$ ), for GSM, indicating acceptable linearity for GSM. The observed $r^{2}$ for 2-MIB in real water is slightly below our internal limit of $\geq 0.995$.

Limit of detection (LOD) and limit of quantitation (LOQ): Standards of concentration 6, 5, 4, 3, 2 and $1 \mathrm{ng} / \mathrm{L}$ in MQ water were analyzed in replicates of 10 . The LOQ was found to be $6 \mathrm{ng} / \mathrm{L}$, with $\mathrm{RSD}=3.25 \%$ (accuracy $=113.72 \%$ ), for $2-\mathrm{MIB}$, and $5 \mathrm{ng} / \mathrm{L}$, with RSD $=7.12 \%$ (accuracy $=80.00 \%$ ) for GSM. The observed data comply with our general acceptable internal limits for recovery and precision.

The LOD was found to be $5 \mathrm{ng} / \mathrm{L}$, with $\mathrm{RSD}=12.38 \%$ (accuracy $=$ $77 \%$ ) for $2-\mathrm{MIB}$, and $4 \mathrm{ng} / \mathrm{L}$, with $\mathrm{RSD}=8.54 \%$ (accuracy $=75 \%$ ), for GSM, in compliance with our internal limits criteria. Our laboratory water quality tests methods (assays) generally utilize this technique for LOD and LOQ determination.

For comparison purposes, use of the $\mathrm{S} / \mathrm{N}$ ratio method for chromatographic methods, gave a LOD and a LOQ of $1 \mathrm{ng} / \mathrm{L}$ for 2 -MIB (mean $\mathrm{S} / \mathrm{N}=38, \mathrm{RSD}=14.06 \%$ ), and $1 \mathrm{ng} / \mathrm{L}$ (mean $\mathrm{S} / \mathrm{N}=116$, $\mathrm{RSD}=13.88 \%)$ for GSM based on the lowest standard used $(1 \mathrm{ng} / \mathrm{L})$. Composite standards of $<1 \mathrm{ng} / \mathrm{L}$ in MQ were not investigated. Although standards $<1 \mathrm{ng} / \mathrm{L}$ were not analyzed, using the observed $\mathrm{S} / \mathrm{N}$ ratios, the theoretical, expected LOQ for 2-MIB and GSM is estimated to be $0.3 \mathrm{ng} / \mathrm{L}$ and $0.1 \mathrm{ng} / \mathrm{L}$, respectively. The sensitivity of our developed test method therefore compares fairly well with the earlier work [35-38]; the observed $(1 \mathrm{ng} / \mathrm{L})$ and theoretical $(0.3$ and $0.1 \mathrm{ng} / \mathrm{L})$ LOQ is an improvement on that reported by Salemi et al [35] who used the $\mathrm{S} / \mathrm{N}$ ratio method (Table 1). No LOQ data was reported by Deng et al. [38].

The serial dilution technique, although it results in higher LOD and LOQ, would tend to be more accurate as selection of the "noise" region in a chromatogram, using the $\mathrm{S} / \mathrm{N}$ method, is biased due to choice by the analyst.

Stability of the water sample at ambient temperature: Stability has been previously reported [37]. For general batch processing, a 
Citation: Manickum T, John W (2012) Method Validation for the Trace Analysis of Geosmin and 2-Methylisoborneol in Water by "Salt-Free" Purgeand-Trap Sampling/GC-MS, Using the Eclipse 4660 Sample Concentrator. Hydrol Current Res 3:134. doi:10.4172/2157-7587.1000134

Page 4 of 10

\begin{tabular}{|c|c|c|c|c|c|c|c|c|c|c|c|c|}
\hline $\begin{array}{l}\text { Sample Conc. } \\
\text { Technique }^{a}\end{array}$ & $\begin{array}{l}\% \mathrm{NaCl} \\
(\mathrm{m} / \mathrm{v})\end{array}$ & $\begin{array}{l}\mathrm{LOD}^{b} \\
\text { 2-MIB }\end{array}$ & $\begin{array}{l}\mathrm{LOQ}^{b} \\
\text { 2-MIB }\end{array}$ & $\begin{array}{l}\mathrm{LOD}^{b} \\
\mathrm{GSM}\end{array}$ & $\begin{array}{l}\mathrm{LOQ}^{b} \\
\mathrm{GSM}^{-}\end{array}$ & $\begin{array}{l}\mathrm{R} \%^{\mathrm{c}} \\
2-\mathrm{MIB}\end{array}$ & $\begin{array}{l}\mathrm{R} \%{ }^{\mathrm{c}} \\
\mathrm{GSM}\end{array}$ & $\begin{array}{l}\text { Within -day } \\
\text { RSD\% 2-MIB }\end{array}$ & $\begin{array}{l}\text { Day-to- day } \\
\text { RSD\% 2-MIB }\end{array}$ & $\begin{array}{l}\text { Within -day } \\
\text { RSD\% GSM }\end{array}$ & $\begin{array}{l}\text { Day-to-day } \\
\text { RSD\% GSM }\end{array}$ & $\operatorname{Ref}^{d}$ \\
\hline SE & - & 5.0 & $\mathrm{nd}^{e}$ & 1.0 & & $>50$ & 80 & nd & nd & nd & nd & [22] \\
\hline SE & - & 1 & 5 & 1 & 5 & 75-85 & $70-80$ & $7-10$ & nd & $10-15$ & nd & [23] \\
\hline SE & - & nd & 0.3 & nd & 0.1 & 58 & 69 & nd & nd & nd & nd & [4] \\
\hline SE & - & 0.1 & 0.3 & 0.1 & 0.3 & $54-101$ & $75-121$ & $6.9-7.8$ & nd & $5.9-6.3$ & nd & [24] \\
\hline SPE & - & nd & nd & nd & nd & $<50$ & $<50$ & nd & nd & nd & nd & [22] \\
\hline SPE & 30 & $<0.4$ & 0.4 & $<0.4$ & 0.2 & nd & nd & 1.6 & nd & 0.6 & nd & [25] \\
\hline SPME & - & 1 & 0.5 & 1 & 0.20 & 118 & 78 & 8.3 & nd & 12.4 & nd & [26] \\
\hline HS-D & 20 & 1 & nd & 1 & nd & nd & nd & nd & nd & nd & nd & [27] \\
\hline HS-SPE & - & 0.1 & 1 & 0.1 & 1 & 115 & 104 & nd & nd & nd & nd & [28] \\
\hline HS-SPME & - & 0.6 & nd & 0.3 & nd & 96 & 97 & nd & nd & nd & nd & [29] \\
\hline HS-SPME & 25 & 15 & nd & 10 & nd & nd & nd & nd & nd & nd & nd & [30] \\
\hline HS-SPME & 25 & nd & nd & nd & nd & $83-97$ & $86-96$ & nd & nd & nd & nd & [31] \\
\hline PT & - & $0.1 \mu \mathrm{g} / \mathrm{kg}$ & $>0.5 \mu \mathrm{g} / \mathrm{kg}$ & $0.1 \mu \mathrm{g} / \mathrm{kg}$ & $>0.5 \mu \mathrm{g} / \mathrm{kg}$ & 39 & 59 & nd & $<7$ & nd & nd & [32] \\
\hline PT & - & nd & nd & nd & nd & nd & nd & $1-48$ & nd & $1-34$ & nd & [33] \\
\hline PT & 10 & 1 & nd & 1 & nd & nd & nd & 6.6 & nd & 4.7 & nd & [34] \\
\hline PT & 25 & 1 & 3.3 & 2 & 6.7 & 85 & 94 & 6.4 & nd & 7.9 & nd & [35] \\
\hline PT & 10 & 1 & 0.2 & 1 & 0.1 & 107 & 104 & 5.8 & nd & 7.4 & nd & [36] \\
\hline PT & - & 1 & 2 & 1 & 2 & $\begin{array}{l}84 \\
117^{f}\end{array}$ & $\begin{array}{l}86 \\
92^{f}\end{array}$ & $\begin{array}{l}8.2 \\
6.4^{f}\end{array}$ & 14.1 & $\begin{array}{l}9.2 \\
4.3^{f}\end{array}$ & 13.7 & [37] \\
\hline PT & - & 1.4 & nd & 0.08 & nd & $\begin{array}{l}99-113 \\
88^{f ;} ; 87^{f}\end{array}$ & $\begin{array}{l}99-116 \\
105^{f ;} ; 103^{f}\end{array}$ & $7.6^{g} ; 7.3^{h}$ & $5.4^{g} ; 4.6^{h}$ & $6.1^{i} ; 3.4 j$ & $1.8^{i} ; 2.2^{j}$ & [38] \\
\hline
\end{tabular}

${ }^{a}$ Conc. = concentration; $\mathrm{D}=$ dynamic; $\mathrm{HS}$ = headspace; $\mathrm{SE}=$ solvent extraction; SPE = solid phase extraction; SPME = solid phase micro extraction;

$\mathrm{PT}=$ purge-and-trap

${ }^{b}$ Units: ng/L, unless otherwise stated; ${ }^{c}$ Recovery from MQ water; ${ }^{d}$ Reference; ${ }^{e} \mathrm{nd}=$ no data reported; ${ }^{f}$ Raw water; ${ }^{g}$ At $2 \mathrm{ng} / \mathrm{L} ;{ }^{h}$ At $100 \mathrm{ng} / \mathrm{L} ;{ }^{i}$ At $20 \mathrm{ng} / \mathrm{L} ;{ }^{j}$ At $300 \mathrm{ng} / \mathrm{L}$

Table 1: Comparison of method performance parameters for trace analysis of GSM and 2-MIB .

\begin{tabular}{|c|c|c|c|c|c|c|}
\hline Matrix & Concentration added (ng/L) & Concentration found Mean \pm SD $(\mathrm{ng} / \mathrm{L})^{a}$ & RSD (\%) & Accuracy/ Recovery Mean \pm SD (\%) & RSD (\%) & Bias (\%) \\
\hline \multicolumn{7}{|c|}{ MQ water } \\
\hline \multirow[t]{3}{*}{ 2-MIB } & 5 & $4.41 \pm 0.48$ & 10.91 & $88.14 \pm 9.62$ & 10.91 & -11.86 \\
\hline & 30 & $26.58 \pm 2.49$ & 9.36 & $88.59 \pm 8.29$ & 9.36 & -11.41 \\
\hline & 100 & $92.27 \pm 4.00$ & 4.34 & $92.27 \pm 4.00$ & 9.18 & -7.73 \\
\hline Mean & & & 8.20 & $89.67 \pm 2.27$ & 9.82 & -10.33 \\
\hline \multirow[t]{3}{*}{ GSM } & 5 & $4.24 \pm 0.19$ & 4.46 & $84.86 \pm 3.79$ & 4.46 & -15.14 \\
\hline & 30 & $27.05 \pm 1.21$ & 4.48 & $90.15 \pm 4.04$ & 4.48 & -9.85 \\
\hline & 100 & $101.94 \pm 4.47$ & 4.38 & $101.94 \pm 4.47$ & 4.38 & +1.94 \\
\hline Mean & & & 4.45 & $92.32 \pm 8.74$ & 4.46 & -10.93 \\
\hline \multicolumn{7}{|c|}{ Potable water } \\
\hline \multirow[t]{3}{*}{ 2-MIB } & 5 & $5.87 \pm 0.43$ & 7.41 & $117.33 \pm 8.69$ & 7.41 & +17.33 \\
\hline & 30 & $38.71 \pm 2.12$ & 5.48 & $129.03 \pm 7.07$ & 5.48 & +29.03 \\
\hline & 100 & $132.58 \pm 3.90$ & 2.94 & $132.58 \pm 3.90$ & 2.94 & +32.58 \\
\hline Mean & & & 5.28 & $126.31 \pm 7.98$ & 5.28 & +26.31 \\
\hline \multirow[t]{3}{*}{ GSM } & 5 & $3.97 \pm 0.25$ & 5.07 & $79.33 \pm 5.08$ & 6.40 & -20.67 \\
\hline & 30 & $25.83 \pm 1.47$ & 5.69 & $86.10 \pm 4.90$ & 5.69 & -13.90 \\
\hline & 100 & $96.34 \pm 6.15$ & 6.38 & $96.34 \pm 6.15$ & 6.38 & -3.66 \\
\hline Mean & & & 5.71 & $87.26 \pm 9.81$ & 6.16 & -12.74 \\
\hline \multicolumn{7}{|c|}{ Raw water } \\
\hline \multirow[t]{4}{*}{ 2-MIB } & 5 & $5.03 \pm 0.62$ & 12.31 & $100.62 \pm 12.39$ & 12.31 & +0.62 \\
\hline & $30^{b}$ & $24.58 \pm 1.83$ & 7.45 & $81.94 \pm \quad 6.10$ & 7.45 & -18.06 \\
\hline & $30^{c}$ & $29.60 \pm 1.37$ & 4.62 & $98.67 \pm 4.56$ & 4.62 & -1.33 \\
\hline & $100^{c}$ & $105.31 \pm 18.24$ & 17.32 & $105.31 \pm 18.24$ & 17.32 & +5.31 \\
\hline Mean & & & 10.43 & $96.64 \pm 10.19$ & 10.43 & -3.37 \\
\hline \multirow[t]{4}{*}{ GSM } & 5 & $3.94 \pm 0.34$ & 8.52 & $78.76 \pm 6.71$ & 8.52 & -21.24 \\
\hline & $30^{b}$ & $17.87 \pm 1.55$ & 8.67 & $59.55 \pm 1.55$ & 8.67 & -40.45 \\
\hline & $30^{c}$ & $22.54 \pm 1.77$ & 7.84 & $75.14 \pm 5.89$ & 7.84 & 24.86 \\
\hline & $100^{c}$ & $91.11 \pm 14.87$ & 16.32 & $91.11 \pm 14.87$ & 16.32 & -7.17 \\
\hline Mean & & & 10.34 & $76.14 \pm 13.00$ & 10.34 & -11.00 \\
\hline
\end{tabular}

${ }^{a}$ After blank correction; ${ }^{b}$ River matrix: Mzinto; ${ }^{c}$ Dam matrix: Nagle Dam Main Basin

Table 2: Accuracy, bias and precision for 2-MIB and GSM ( $n=10$ replicates). 
Citation: Manickum T, John W (2012) Method Validation for the Trace Analysis of Geosmin and 2-Methylisoborneol in Water by "Salt-Free" Purgeand-Trap Sampling/GC-MS, Using the Eclipse 4660 Sample Concentrator. Hydrol Current Res 3:134. doi:10.4172/2157-7587.1000134

Page 5 of 10

\begin{tabular}{|c|c|c|c|c|c|c|}
\hline Daya & $\begin{array}{l}\text { Calibration } \\
\text { standard (ng/L) }\end{array}$ & $\begin{array}{l}2-M-2-B t_{r} \\
(\min )\end{array}$ & $\begin{array}{l}\text { 2-M-2-B } \\
\text { area }\end{array}$ & $\begin{array}{l}\text { 2-MIB } t_{r} \\
(\min )\end{array}$ & $\begin{array}{l}\text { 2-MIB } \\
\text { area }\end{array}$ & $\begin{array}{c}\% \text { Area } 2-M-2-B \\
\text { of total }^{\mathrm{b}}\end{array}$ \\
\hline \multicolumn{7}{|l|}{3} \\
\hline & 5 & 9.23 & 115085 & 11.99 & 578029 & 16.60 \\
\hline & 10 & 9.22 & 89009 & 11.99 & 801441 & 10.00 \\
\hline & 20 & 9.19 & 183669 & 11.99 & 1451559 & 11.23 \\
\hline & 30 & 9.18 & 305983 & 11.99 & 1936662 & 13.64 \\
\hline & 50 & 9.19 & 810465 & 11.99 & 3112143 & 20.66 \\
\hline & 100 & 9.19 & 1488939 & 11.99 & 5978289 & 19.94 \\
\hline & Mean & 9.20 & & 11.99 & & 15.35 \\
\hline & SD & 0.02 & & 0.00 & & 4.46 \\
\hline & RSD\% & 0.22 & & 0.02 & & 29.05 \\
\hline \multirow[t]{9}{*}{4} & 5 & 9.19 & 142490 & 11.99 & 259754 & 35.42 \\
\hline & 10 & 9.18 & 265349 & 11.99 & 430539 & 38.13 \\
\hline & 20 & 9.19 & 440118 & 11.99 & 764791 & 36.53 \\
\hline & 30 & 9.18 & 656460 & 11.99 & 1236145 & 34.69 \\
\hline & 50 & 9.18 & 1116240 & 11.99 & 2049664 & 35.26 \\
\hline & 100 & 9.18 & 2585342 & 11.99 & 4001196 & 39.25 \\
\hline & Mean & 9.18 & & 11.99 & & 36.55 \\
\hline & SD & 0.00 & & 0.00 & & 1.80 \\
\hline & RSD \% & 0.05 & & 0.02 & & 4.93 \\
\hline
\end{tabular}

${ }^{a}$ Calibration run for day 3 and day 4

${ }^{b}$ Calculated as follows: [TIC area of 2-M-2-B (at $\left.\pm 9.2 \mathrm{~min}\right) /(\mathrm{TIC}$ area of 2-M-2-B (at $\pm 9.2 \mathrm{~min})+$ TIC area of 2-MIB (at $\pm 12.0 \mathrm{~min}))] 100$ Table 3: Within-day variation of 2-M-2-B formation.

maximum of 50 samples can be run during a total run time of $\pm 34 \mathrm{hr}$. $(50 \times 41$ min per sample). Typical batch sizes of less than 50 samples can therefore be run in just over $24 \mathrm{hr}$.

It was noted that that area counts for geosmin, especially at low concentration, tend to decrease on standing of the sample at room temperature. Maintaining the water samples chilled whilst stored in the autosampler rack until the time of sample analysis, has shown stability of geosmin. This is an important factor to consider when analyzing drinking water samples for presence of geosmin.

Accuracy: The accuracy was determined by assessing recovery of added analytes to MQ and raw water, and by analyzing internal Analytical Quality Control (AQC) material.

The results are summarized in Table 2.

For MQ water, overall accuracy was $89.67 \% \pm 2.27$ (mean RSD = $9.82 \%$ ) for $2-\mathrm{MIB}$, and $92.32 \% \pm 8.74$ (mean $\mathrm{RSD}=4.46 \%$ ) for GSM respectively. The average bias was $-10.33 \%$ and $-10.93 \%$ for 2 -MIB and GSM, respectively. These results indicate acceptable accuracy for both GSM and 2-MIB with reference to our internal limits.

For potable water, overall accuracy was $126.31 \% \pm 7.98$ (mean RSD $=5.28 \%)$ for $2-\mathrm{MIB}$, and $87.26 \% \pm 9.81$ (mean RSD $=6.16 \%)$ for GSM respectively. The average bias was $+26.31 \%$ and $-12.74 \%$ for 2 -MIB and GSM, respectively. The observed accuracy for 2-MIB exceeds our internal upper limit of $120 \%$; the results indicate acceptable accuracy for GSM.

For raw water, corresponding values were $96.64 \% \pm 10.19$ (mean $\mathrm{RSD}=10.43$ ) for $2-\mathrm{MIB}$, and $76.14 \% \pm 13.06 \%$ (mean RSD $=10.34 \%)$ for GSM, respectively (Table 2). The average bias was $-3.37 \%$ and $-11.00 \%$ for 2 -MIB and GSM, respectively. These results indicate acceptable accuracy for 2-MIB; the observed accuracy for GSM is slightly below our internal lower limit of $80 \%$.

A freshly prepared AQC at $30 \mathrm{ng} / \mathrm{L}$ in MQ water, assayed over 10 days, gave overall accuracy of $88.47 \%(\mathrm{RSD}=28.71 \%)$ for 2 -MIB, and

$89.07 \%(\mathrm{RSD}=20.70 \%)$ for GSM. The corresponding bias was $-11.53 \%$ for 2 -MIB and $-10.93 \%$ for GSM. These results indicate acceptable accuracy for both GSM and 2-MIB with reference to our internal limits.

Precision: Instrument precision (repeatability) was determined by assay of 10 replicates of standards at 5, 30 and $100 \mathrm{ng} / \mathrm{L}$. For MQ water, using peak areas, RSD\% was 10.91, 9.18 and 3.735 for 5, 30 and 100 $\mathrm{ng} / \mathrm{L}$ (mean $\mathrm{RSD}=7.94$ ) for 2-MIB. The corresponding values for GSM were $4.02 \%, 4.51 \%$ and $1.80 \%$, for 5,30 and $100 \mathrm{ng} / \mathrm{L}$ (mean RSD = $3.44 \%)$ respectively.

Method precision was determined for both repeatability and reproducibility by analysis of standards at 5, 10, 30 and $100 \mathrm{ng} / \mathrm{L}$ in MQ water and raw water. Repeatability was studied by replicate analysis for $\mathrm{n}=10$ aliquots. Reproducibility was determined by assaying two to four aliquots of freshly prepared standard, $30 \mathrm{ng} / \mathrm{L}$, on $\mathrm{n}=10$ different days.

The Repeatability RSD for 2-MIB in MQ water averaged $8.20 \%$ at 5 , $30,100 \mathrm{ng} / \mathrm{L}$. The corresponding average for potable and raw water was $5.28 \%$ and $10.43 \%$ (Table 2).

The Repeatability RSD for GSM in MQ water averaged $4.45 \%$ at 5 , $30,100 \mathrm{ng} / \mathrm{L}$. The corresponding average for potable and raw water was $5.58 \%$ and $6.23 \%$ (Table 2).

The Reproducibility RSD for the $30 \mathrm{ng} / \mathrm{L}$ AQC, assayed over 10 days, was $20.96 \%$ (mean concentration $=27.49 \mathrm{ng} / \mathrm{L}, \mathrm{SD}=5.76$ ) for $2-\mathrm{MIB}$, and $7.52 \%$ (mean concentration $=27.67 \mathrm{ng} / \mathrm{L}, \mathrm{SD}=2.08$ ) for GSM, respectively.

The precision data obtained for the AQC, $30 \mathrm{ng} / \mathrm{L}$ concentration, indicates an RSD of $9.36 \%$ for within-day variation, and $20.96 \%$ for day-to-day variation, for 2-MIB. The corresponding within-day and day-to-day precision, on the same sample concentration, for GSM, is $4.48 \%$ and $7.52 \%$. The relatively poor day-to-day precision obtained for 2 -MIB is presumably due to the dehydration of 2 -MIB to $2-\mathrm{M}-2-\mathrm{B}$, as observed earlier [45].

The dehydration of 2-MIB was studied further regarding the relative amount of 2-M-2-B formed as a percentage of the total amount of 2-MIB and 2-M-2-B. For this purpose, the within-day and day-today precision data obtained for the assay of the $30 \mathrm{ng} / \mathrm{L}$ standard, and the calibration data, was analyzed. The data are summarized in Table 3 ; other data are available as supplementary material (Supplementary Tables 1, 2, 3, 4).

For the within-day assay variation for the assay of the $30 \mathrm{ng} / \mathrm{L}$ standard, the precision data for 2-MIB assay, TIC peak area and $\mathrm{m} / \mathrm{z}$ 95 areas are all less than $10 \%$. The RSD for the percentage of $2-\mathrm{M}-2-\mathrm{B}$ formed or present is much better, at $3.31 \%$. The precision data for TIC peak area for $2-\mathrm{M}-2-\mathrm{B}$ and $\mathrm{m} / \mathrm{z} 95$ areas for $2-\mathrm{M}-2-\mathrm{B}$ is also less than $10 \%$. Regarding the day-to-day variation for the assay of the AQC (30 $\mathrm{ng} / \mathrm{L}$ ), the precision data for the assay, TIC peak area and $\mathrm{m} / \mathrm{z} 95$ peak area range from $21-27 \%$. For $2-\mathrm{M}-2-\mathrm{B}$, the precision for the TIC peak area and the $\mathrm{m} / \mathrm{z} 95$ peak area averages $49 \%$. The RSD for the percentage of 2-M-2-B formed or present averaged 34\%.

For GSM, the within-day variation for the assay of the $30 \mathrm{ng} / \mathrm{L}$ standard, TIC peak area and m/z 112 peak areas are all less than $5 \%$. The day-to-day precision data for the assay of the AQC is less than $10 \%$. However, the day-to-day precision for the TIC peak area and $\mathrm{m} / \mathrm{z} 112$ peak areas averaged $20 \%$.

Regarding the precision data on the relative amount of 2-M-2-B formed, the calibration standards of 5-100 ng/L in MQ water that were 


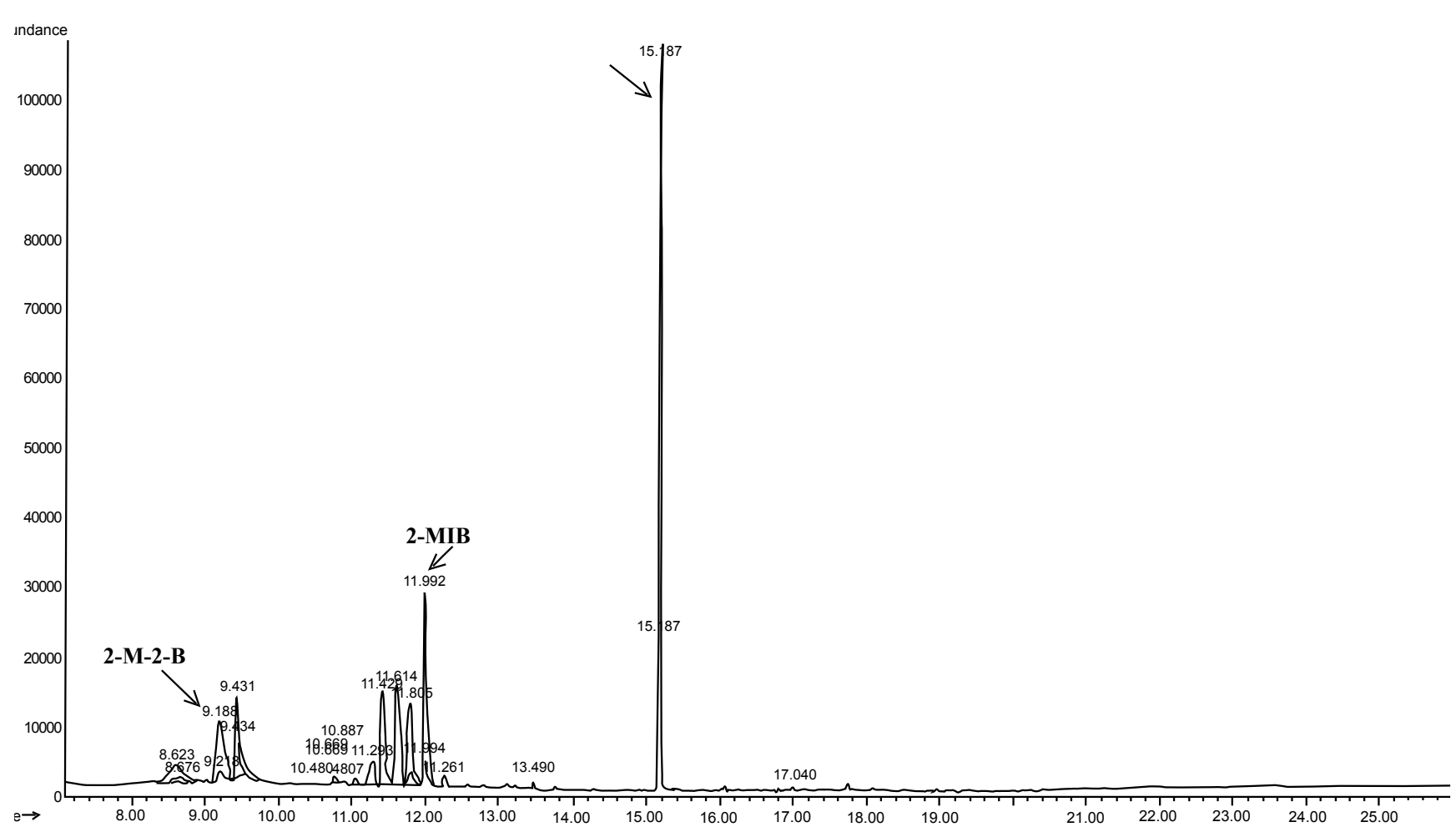

Figure 1: Overlay total ion chromatogram of raw water after extraction: unspiked and spiked, at $30 \mathrm{ng} / \mathrm{L}:$ : $-\mathrm{M}-2-\mathrm{B}$ (9.218 min, $9.188 \mathrm{~min}), 2-\mathrm{MIB}$ (RT 11.994 min, $11.992 \mathrm{~min})$, GSM (RT $15.187 \mathrm{~min}, 15.187 \mathrm{~min})$

run during the method validation (day 1 to day $10, \mathrm{n}=10$ days) were analyzed.

The data are summarized in Table 3 (within-day precision) and Table 3 (day-to-day precision, available as supplementary data).

Within-day precision:

The calibration data for day 3 and day 4 were chosen to illustrate the two extreme variations of average percentage of 2-M-2-B formed within a day: $15 \%$, with $\mathrm{RSD}=29.05 \%$ (poor) and $37 \%$, with $\mathrm{RSD}=$ $4.93 \%$ (good), i.e., $<10 \%$.

Day-to-day precision:

The data is available as supplementary material (Table 7). The average percentage formation of $2-\mathrm{M}-2-\mathrm{B}$, during any day, is $27 \% \pm 9$ (range: $15-50 \%$ ) with $\mathrm{RSD}=33.26 \%$, i.e., $>>10 \%$.

\section{Application}

An extracted sample of raw water (Umzinto River), and the same matrix sample, spiked with target compounds at concentration of 30 $\mathrm{ng} / \mathrm{L}$, showed that there were no interfering peaks from the sample matrix. A typical Total Ion Chromatogram (TIC) is illustrated in Figure 1: overlapped chromatograms of the extracted raw water and spiked raw water. The unspiked sample and spiked sample showed 2-MIB, at $11.994 \mathrm{~min}$ and $11.992 \mathrm{~min}$ and GSM, at $15.187 \mathrm{~min}$ and $15.187 \mathrm{~min}$ respectively.

A raw water sample and a potable sample were analyzed in replicates of 10. For Amanzimtoti raw and Umzinto River raw water, the observed concentrations for 2-MIB and GSM were below the limit of quantitation ( $<6$ and $<5 \mathrm{ng} / \mathrm{L}$, respectively).

For raw water collected from Nagle Dam main basin, the observed concentration for 2-MIB and GSM was $<6 \mathrm{ng} / \mathrm{L}$ and $17.07 \mathrm{ng} / \mathrm{L}$ ( $\mathrm{n}=9$ replicates, $\mathrm{SD}=3.71, \mathrm{RSD}=21.72 \%$ ), respectively.

\section{Relative amount of 2-M-2-B formed as a function of 2-MIB concentration}

To check the amount of 2-M-2-B formed with varying concentration of 2-MIB, the calibration data, using the 5-100 ng/L standards in MQ water, for the day 1 to through to day 10 were analyzed.

The results are available as supplementary material (summarized in Table 8). Regression analysis showed fairly good linearity. The correlation coefficient $r^{2}$, determined over 10 days, averaged 0.994 $(\mathrm{SD}=0.005$, RSD $=0.48 \%)$, mean $a=17402(\mathrm{SD}=6337, \mathrm{RSD}=$ $36.42 \%)$. There is thus a linear relationship between the amount of 2-M-2-B formed and the initial concentration of 2-MIB. It is, however, evident that the variation in slope of the graph exceeds $10 \%$, implying a significant variation in the amount of 2-M-2-B formed over different days, from the same initial standard concentration of 2-MIB.

\section{Effect of sample temperature on dehydration of 2-MIB and sensitivity}

An experiment was conducted to check effect of sample temperature during the 11 min purge cycle over the range $20-80^{\circ} \mathrm{C}$, in $10^{\circ} \mathrm{C}$ increments, on the dehydration of 2-MIB, sensitivity of response for 2-MIB, and for GSM. Composite standards of concentration 200 
Citation: Manickum T, John W (2012) Method Validation for the Trace Analysis of Geosmin and 2-Methylisoborneol in Water by "Salt-Free" Purgeand-Trap Sampling/GC-MS, Using the Eclipse 4660 Sample Concentrator. Hydrol Current Res 3:134. doi:10.4172/2157-7587.1000134

Page 7 of 10

\begin{tabular}{|c|c|c|c|c|c|}
\hline $\mathrm{T}\left({ }^{\circ} \mathrm{C}\right)^{b}$ & $\mathrm{t}_{\mathrm{r}}(\min )^{c}$ & Peak area & $t_{r}(\min )$ & Peak area $^{c}$ & $\begin{array}{c}\% \text { Area of 2-M-2-B } \\
\text { of total }\end{array}$ \\
\hline \multicolumn{6}{|l|}{ SCAN $^{a}$} \\
\hline 20 & - & - & 11.980 & 276420 & - \\
\hline 30 & - & - & 12.028 & 1158064 & - \\
\hline 40 & 9.174 & 1114861 & 11.986 & 3536478 & 24 \\
\hline 50 & 9.175 & 2793335 & 11.984 & 5613065 & 33 \\
\hline 60 & 9.169 & 5691336 & 11.983 & 10491636 & 35 \\
\hline 70 & 9.168 & 5532433 & 11.985 & 12412558 & 31 \\
\hline 80 & 9.172 & 6510569 & 11.985 & 17251559 & 27 \\
\hline Mean & 9.172 & 4328507 & & 7248540 & 30 \\
\hline SD & 0.004 & 2277741 & & 6316693 & 4 \\
\hline RSD $\%$ & 0.05 & 52.62 & & 87.14 & 14.93 \\
\hline \multicolumn{6}{|l|}{$\mathrm{SIM}^{a}$} \\
\hline 20 & - & - & - & - & - \\
\hline 30 & - & - & 11.989 & 457787 & 0 \\
\hline 40 & 9.171 & 233543 & 11.984 & 545015 & 30 \\
\hline 50 & 9.170 & 386850 & 11.984 & 1035640 & 27 \\
\hline 60 & 9.175 & 609005 & 11.985 & 1622511 & 27 \\
\hline 70 & 9.178 & 819173 & 11.986 & 2352676 & 26 \\
\hline 80 & 9.188 & 782252 & 11.990 & 3369163 & 19 \\
\hline Mean & 9.176 & 566165 & 11.986 & 1563799 & 26 \\
\hline SD & 0.007 & 252653 & 0.003 & 1133600 & 4 \\
\hline RSD $\%$ & 0.08 & 44.63 & 0.02 & 72.49 & 16.22 \\
\hline
\end{tabular}

a $200 \mathrm{ng} / \mathrm{L}$ and $100 \mathrm{ng} / \mathrm{L}$ composite standard of 2-MIB/GSM in MQ water, for ful scan and SIM modes respectively

${ }^{b}$ Sample purge temperature

${ }^{c}$ Retention times of target compounds

${ }^{d}$ Calculated as follows: [(Area of 2-M-2-B/(area of 2-M-2-B + area of 2-MIB) $] 100$ using TIC response

Table 4: Effect of sample purge temperature on dehydration and sensitivity of 2-MIB.

$\mathrm{ng} / \mathrm{L}$ and $100 \mathrm{ng} / \mathrm{L}$, in MQ water, were run in full scan and SIM modes, respectively. Results, based on a single run for each temperature and MS mode, are summarized in Table 4, for 2-MIB, and in Table 5, for GSM, respectively.

The ratio for mass fragments $\mathrm{m} / \mathrm{z} 95 / 107$ and $\mathrm{m} / \mathrm{z}$ 150/107 has been used to confirm presence of the 2-MIB dehydration product, 2-M-2-B [45]. The ratio for mass fragments $\mathrm{m} / \mathrm{z} 107 / 95$ and $\mathrm{m} / \mathrm{z}$ 108/95 has been used to confirm presence of 2-MIB [45]. The latter observations were used for peak identification for the full scan and SIM mode data listed in Table 3.

In the full scan mode, examination of the results (Table 4 ) obtained indicate that at sample purge temperatures of $20-30^{\circ} \mathrm{C}$, there is no evidence of formation of 2-M-2-B, and 2-MIB appears to be present at sample purge temperature of $20^{\circ} \mathrm{C}$ upward. The results indicate an overall increase in peak area at $9.2 \mathrm{~min}\left(1.1 \times 10^{6}\right.$ to $\left.6.5 \times 10^{6}\right)$ and at 12.0 $\min ,\left(3.5 \times 10^{6}\right.$ to $\left.17.3 \times 10^{6}\right)$, as the sample purge temperature increases from $40^{\circ} \mathrm{C}$ to $80^{\circ} \mathrm{C}$. Since $2-\mathrm{M}-2-\mathrm{B}$ is a dehydration product of $2-\mathrm{MIB}$, this observation is expected. Further examination of the area responses for 2-M-2-B indicates an increase from $40^{\circ} \mathrm{C}$, up to $60^{\circ} \mathrm{C}$. With further increase in temperature, above $60^{\circ} \mathrm{C}$ to $80^{\circ} \mathrm{C}$, there is no significant increase or change in area response for 2-M-2-B. However, for 2-MIB, there is a definite linear increase or change in area response as sample purge temperature increases from $20^{\circ} \mathrm{C}$ to $80^{\circ} \mathrm{C}$.

In the SIM mode, examination of the results (Table 4) obtained indicate that at sample purge temperatures of $20-30^{\circ} \mathrm{C}$, there is no evidence of formation of 2-M-2-B, and no evidence of 2-MIB at sample purge temperature of $20^{\circ} \mathrm{C}$. In SIM mode, $2-\mathrm{MIB}$ can be detected from $30^{\circ} \mathrm{C}$ sample purge temperature, while in full scan mode the minimum temperature is $20^{\circ} \mathrm{C}$, using a higher sample concentration of $200 \mathrm{ng} / \mathrm{L}$. The results indicate an increase in peak area at $9.2 \mathrm{~min},\left(0.2 \times 10^{6}\right.$ to 0.8 $\times 10^{6}$ area units), and at $12.0 \mathrm{~min}$. $\left(0.5 \times 10^{6}\right.$ to $3.4 \times 10^{6}$ area units $)$, as the sample purge temperature increases from $40^{\circ} \mathrm{C}$ to $80^{\circ} \mathrm{C}$ : 0.2 million to 0.8 million area units. Since $2-\mathrm{M}-2-\mathrm{B}$ is a dehydration product of $2-\mathrm{MIB}$, this observation is expected. Overall, these results indicate that 2 -MIB can be purged at a minimum temperature of $30^{\circ} \mathrm{C}$ from water, with no apparent dehydration. The average daily percentage formation of $2-\mathrm{M}-2-\mathrm{B}$ was estimated to be $27 \%$, with $33 \%$ RSD. It is therefore advisable to use $30^{\circ} \mathrm{C}$ sample purge temperature for 2-MIB analysis in water.

We also determined the percentage of 2-M-2-B formed, expressed as a percentage of the sum of the TIC areas of 2-M-2-B and 2-MIB, and over the temperature range studied $40-80^{\circ} \mathrm{C}$. For the full scan and SIM mode determination, the average percentage is $30 \%$ and $26 \%$, respectively. The overall percentage is $23 \%$. It is apparent that the dehydration of $2-\mathrm{MIB}$, and hence formation of $2-\mathrm{M}-2-\mathrm{B}$ (RSD $=16 \%$ in full scan and SIM mode), is fairly constant over the sample purge temperature studied (Table 4 ).

Similar method development work on the Eclipse 4660 by Deng et al. [38], showed an optimum sample purge temperature of $55^{\circ} \mathrm{C}$. Over the temperature range studied $\left(30-80^{\circ} \mathrm{C}\right)$, there was no report of the presence of 2-M-2-B, or 2-MB. Regarding the mass spectral analysis of 2 -MIB, the author reported relative intensity of $100 \%$ for $\mathrm{m} / \mathrm{z} 95$, and $29 \%$ for m/z 108; no relative intensity was reported for m/z 107 [48].

\section{Effect of sample purge temperature on GSM sensitivity}

The ratio for mass fragments $\mathrm{m} / \mathrm{z} 111 / 112$ and $125 / 112$ has been used to confirm presence, or identification, of GSM [21]. The results obtained are summarized in Table 5.

\begin{tabular}{|c|c|c|}
\hline Sample ${ }^{a}$ Temperature $\left({ }^{\circ} \mathrm{C}\right)$ & $t_{r} \min$ & Peak area $^{b}$ \\
\hline \multicolumn{3}{|l|}{ SCAN } \\
\hline 20 & - & - \\
\hline 30 & - & - \\
\hline 40 & 15.185 & 4051143 \\
\hline 50 & 15.185 & 8746685 \\
\hline 60 & 15.185 & 15010297 \\
\hline 70 & 15.185 & 20691559 \\
\hline 80 & 15.184 & 29096795 \\
\hline Mean & 15.185 & \\
\hline SD & 0.001 & \\
\hline RSD $\%$ & 0.00 & \\
\hline \multicolumn{3}{|l|}{ SIM } \\
\hline 20 & - & - \\
\hline 30 & 15.187 & 240418 \\
\hline 40 & 15.185 & 591398 \\
\hline 50 & 15.184 & 1248035 \\
\hline 60 & 15.184 & 2131626 \\
\hline 70 & 15.184 & 3165161 \\
\hline 80 & 15.184 & 4201134 \\
\hline Mean & 15.184 & \\
\hline SD & 0.001 & \\
\hline RSD $\%$ & 0.00 & \\
\hline
\end{tabular}

a $200 \mathrm{ng} / \mathrm{L}$ and $100 \mathrm{ng} / \mathrm{L}$ composite standard of 2-MIB/GSM in MQ water, for ful scan and SIM mode respectively

${ }^{b}$ From the TIC

Table 5: Effect of sample purge temperature on sensitivity of GSM. 
In the full scan mode, examination of the results (Table 5) obtained indicate that at sample purge temperatures of $20-30^{\circ} \mathrm{C}$, there is no evidence of presence of GSM. The results indicate an increase in peak area for GSM, as the sample purge temperature increases from $40^{\circ} \mathrm{C}$ to $80^{\circ} \mathrm{C}: 4.1 \times 10^{6}$ to $29.1 \times 10^{6}$ area units.

In the SIM mode, examination of the results (Table 5) obtained indicate that at sample purge temperature of $20^{\circ} \mathrm{C}$, there is no presence of GSM. However, due to the generally relatively increased sensitivity of SIM over full scan mode, the results indicate the presence of GSM at $30^{\circ} \mathrm{C}$ sample purge temperature. Thus, a minimum temperature of $30^{\circ} \mathrm{C}$ is required to purge GSM from a water sample under the conditions employed (11 min, with helium gas). The results indicate an increase in GSM as the sample purge temperature increases from $30^{\circ} \mathrm{C}$ to $80^{\circ} \mathrm{C}: 0.2$ $\times 10^{6}$ to $4.2 \times 10^{6}$ area units. Overall, these results indicate that GSM can be purged at a minimum temperature of $30^{\circ} \mathrm{C}$ from water.

\section{Effect of sample purge temperature at the limit of quantitation}

The odor threshold for 2-MIB and GSM is 5-42 ng/L and 1-10 ng/L respectively. The method validation of our current purge-and-trap method indicated a LOQ of $6 \mathrm{ng} / \mathrm{L}$ and $5 \mathrm{n} / \mathrm{gL}$ for 2 -MIB and GSM. The linear range of our method is 5-100 $\mathrm{ng} / \mathrm{L}$. The effect of sample purge temperature on sensitivity at $100 \mathrm{ng} / \mathrm{L}$ concentration has been discussed above. In view of the low odor threshold of these tasteodorants, it was relevant to study the effect of sample purge temperature on the sensitivity at $5 \mathrm{ng} / \mathrm{L}$ concentration. A composite standard of $5 \mathrm{ng} / \mathrm{L}$ in MQ water was assayed in the SIM mode in duplicate; the usual calibration standards were used to quantitate 2-MIB and GSM concentrations. Results are summarized in Table 6.

The observed retention times for 2-M-2-B, 2-MIB and GSM are $9.182 \mathrm{~min}, 11.986 \mathrm{~min}$ and $15.186 \mathrm{~min}$ respectively.

For 2-MIB there is no evidence of 2-M-2-B, or 2-MIB at sample purge temperatures $20-30^{\circ} \mathrm{C}$; at a sample purge temperature of $40^{\circ} \mathrm{C}$, and higher, both 2-M-2-B and 2-MIB are present. Thus, a minimum sample purge temperature of $40^{\circ} \mathrm{C}$ is required to purge 2-MIB from water to enable detection by MS in SIM mode at $5 \mathrm{ng} / \mathrm{L}$ concentration. The mean percentage of $2-\mathrm{M}-2-\mathrm{B}$ formation is $23 \%$ over the temperature range $40-80^{\circ} \mathrm{C}$. As with our results obtained with the $100 \mathrm{ng} / \mathrm{L}$ standard, there is a proportional increase in peak area of $2-\mathrm{MIB}$, and 2-M-2-B with an increase in temperature. The results indicate acceptable accuracy $($ recovery $=104 \%)$ for $2-\mathrm{MIB}$ at the sample purge temperature of $60^{\circ} \mathrm{C}$.
For GSM there is no evidence of its presence at sample purge temperatures $20-30^{\circ} \mathrm{C}$; at a sample purge temperature of $40^{\circ} \mathrm{C}$ and higher, there is evidence of GSM. Thus a minimum sample purge temperature of $40^{\circ} \mathrm{C}$ is required to purge GSM from water to enable detection by $\mathrm{MS}$ at $5 \mathrm{ng} / \mathrm{L}$ concentrations. As with our results obtained with the $100 \mathrm{ng} / \mathrm{L}$ standard, there is a proportional increase in peak area of GSM with an increase in sample purge temperature. The results indicate acceptable accuracy $(87-116 \%)$ at sample purge temperatures $60-70^{\circ} \mathrm{C}$.

An increased number of replicate runs are further required to confirm these preliminary findings. The analysis of these target compounds by purge-and-trap using the Stratum PTC was recently reported [25] in an Application Note. Although a Method Detection Level (MDL) of $<1 \mathrm{ng} / \mathrm{L}$ was reported, there is no data on the day-today variation; $10 \%(\mathrm{~m} / \mathrm{v})$ deionized salt water solution was used.

\section{Detection of 2-methylene-bornane (2-MB)}

The dehydration of 2-MIB has been shown to produce 2-MB, in addition to 2-M-2-B [44]. Peaks eluting at 10.665 and at $11.4-11.8$ min. appear to be present in both the raw and in MQ water samples in the SIM mode. For this mass spectral analysis, the "quality fit" for the observed peaks ranged from 11-52\%; the latter was also observed for the full scan mass spectra at temperatures $20-70^{\circ} \mathrm{C}$.

\section{Overall findings}

This further study regarding the trace analysis of taste-odorants 2-MIB and GSM, by purge-and-trap/GC-MS, specifically the Eclipse 4660 sample concentrator has indicated the following:

The test method is linear for both 2-MIB and GSM over the concentration range 5-100 ng/L, for MQ water, potable and raw water matrices. The overall accuracy for 2-MIB and GSM, determined by recovery, over the range 5-100 ng/L, for MQ water, potable and raw water matrices is acceptable. The within-day variation for 2-MIB and GSM, over the range 5-100 ng/L, averaged for MQ water, potable and raw water matrices is also acceptable.

The day-to-day variation for MQ water, at $30 \mathrm{ng} / \mathrm{L}$ concentration, is poor for 2-MIB but acceptable for GSM. Unlike the Stratum, it is not necessary to add $1 \%(\mathrm{v} / \mathrm{v})$ methanol to the water sample before extraction, to achieve comparable, sensitivity. The LOQ is $6 \mathrm{ng} / \mathrm{L}$ for

\begin{tabular}{|c|c|c|c|c|c|c|c|c|c|c|}
\hline $\begin{array}{l}\text { Sample }{ }^{a} \text { Tempera- } \\
\text { ture }\left({ }^{\circ} \mathrm{C}\right)\end{array}$ & $\begin{array}{l}\text { Peak Area } \\
\text { at } \pm 9.2 \text { min. }^{b}\end{array}$ & $\begin{array}{l}\text { Peak Area } \\
\text { At } \pm 12.0 \mathrm{~min} .{ }^{b}\end{array}$ & $\begin{array}{l}\% \text { Area of } \\
2-\mathrm{M}-2-\mathrm{B} \text { of total }\end{array}$ & $\begin{array}{l}\text { Peak Area } \\
\text { At } \pm 15.2 \text { min. }\end{array}$ & $\begin{array}{l}\text { 2-MIB Area } \\
\mathrm{m} / \mathrm{z} 95^{d}\end{array}$ & $\begin{array}{l}\text { GSM Area } \\
\mathrm{m} / \mathrm{z} 112^{d}\end{array}$ & $\begin{array}{l}\text { 2-MIB Assay } \\
(\mathrm{ng} / \mathrm{L})^{e}\end{array}$ & $\begin{array}{l}\text { 2-MIB Accuracy } \\
(\%)^{f}\end{array}$ & $\begin{array}{l}\text { GSM Assay } \\
(\mathrm{ng} / \mathrm{L})^{e}\end{array}$ & $\begin{array}{l}\text { GSM Accu- } \\
\text { racy }(\%)^{f}\end{array}$ \\
\hline 20 & $\mathrm{nd}^{g}$ & nd & & nd & nd & nd & & & & \\
\hline 30 & nd & nd & & nd & nd & nd & & & & \\
\hline 40 & 20723 & 45073 & 31 & 49310 & 25845 & 35975 & 1.44 & 28.80 & 1.13 & 22.60 \\
\hline 50 & 28201 & 87730 & 24 & 103403 & 54193 & 75586 & 3.01 & 60.20 & 2.37 & 47.40 \\
\hline 60 & 50705 & 160373 & 24 & 188463 & 93474 & 138392 & 5.19 & 103.80 & 4.34 & 86.80 \\
\hline 70 & 52297 & 221145 & 19 & 257964 & 123511 & 185826 & 6.85 & 137.00 & 5.82 & 116.40 \\
\hline 80 & 56667 & 304435 & 16 & 356702 & 174907 & 256176 & 9.71 & 194.20 & 8.02 & 160.40 \\
\hline Mean & & & 23 & & & & & & & \\
\hline SD & & & 6 & & & & & & & \\
\hline RSD \% & & & 25.08 & & & & & & & \\
\hline
\end{tabular}

a $5 \mathrm{ng} / \mathrm{L}$ composite of 2-MIB/GSM in MQ water

${ }^{b}$ From the TIC, in SIM mode, by manual integration

${ }^{c}=[($ Area of 2-M-2-B/(area of 2-M-2-B + area of 2-MIB $)] 100$, using TIC responses

${ }^{d}$ from SIM chromatogram, at respective $t$; extracted ions m/z 95, 107 (for 2-M-2-B, 2-MIB) and m/z 112 (for GSM)

${ }^{e}$ By calibration, using the normal composite standards of 2-MIB/GSM in MQ water

${ }^{f}$ By recovery

${ }^{g}$ Not detected 
Citation: Manickum T, John W (2012) Method Validation for the Trace Analysis of Geosmin and 2-Methylisoborneol in Water by "Salt-Free" Purgeand-Trap Sampling/GC-MS, Using the Eclipse 4660 Sample Concentrator. Hydrol Current Res 3:134. doi:10.4172/2157-7587.1000134

Page 9 of 10

2-MIB and $5 \mathrm{ng} / \mathrm{L}$ for GSM; $1 \mathrm{ng} / \mathrm{L}$ was observed for 2-MIB and GSM using the S: $\mathrm{N}$ ratio method. The LOD is $5 \mathrm{ng} / \mathrm{L}$ for $2-\mathrm{MIB}$ and $4 \mathrm{ng} / \mathrm{L}$ for GSM; $1 \mathrm{ng} / \mathrm{L}$ was observed using the S: N ratio method.

The reported LOQ for the previously reported method by Salemi et al. [35], determined by the $\mathrm{S} / \mathrm{N}$ ratio method, is 3.3 and $6.7 \mathrm{ng} / \mathrm{L}$; no LOQ was reported by Deng et al. However, the calculated LOQ, based on the observed LOD, is $28 \mathrm{ng} / \mathrm{L}$ for $2-\mathrm{MIB}$ and $1.6 \mathrm{ng} / \mathrm{L}$ for GSM [48]. The relatively poor reproducibility observed for 2-MIB ( $\mathrm{RSD}=20.96 \%$ ), at $30 \mathrm{ng} / \mathrm{L}$ concentration, is proposed to be due to the dehydration of 2-MIB to 2-M-2-B and also to the observation that the percentage formation of 2-M-2-B in samples of concentration covering the linear range of the test method, 5-100 ng/L, varies considerably on a day-to-day basis $(\mathrm{RSD}=33 \%)$.

A minimum sample purge temperature of $30^{\circ} \mathrm{C}$ is required to purge 2-MIB and GSM from water, which can be detected by GC/ MS under our purge-trap conditions at a concentration of $100 \mathrm{ng} / \mathrm{L}$. At this temperature, a $5 \mathrm{ng} / \mathrm{L}$ sample is not detected by GC/MS under the current purge-and-trap/GC-MS conditions. A slightly higher temperature of $40^{\circ} \mathrm{C}$ is required for detection of 2-MIB and GSM at the lower concentration. There is evidence of dehydration of 2-MIB to 2-M-2-B at sample purge temperature of $40^{\circ} \mathrm{C}$ and higher. The average estimated percentage of $2-\mathrm{M}-2-\mathrm{B}$ formation at the sample purge temperature of $80^{\circ} \mathrm{C}$ is $27 \%$ (range: $15-50 \%$ ).

Our work is the second report regarding the full method validation of the Eclipse 4660 purge-and-trap for trace analysis of taste-odorants: 2-MIB and GSM, and also the first report comparing the performance of two currently available purge-and-trap instruments. The best results overall appear to be achievable on the Eclipse 4660 sample concentrator. The validation data for our developed purge-and-trap method, on the Eclipse instrument, shows that the technique does not appear to be reproducible for the trace analysis of 2-MIB. Our previous work on the Stratum indicated day-to-day variation of $>10 \%$ RSD (14\%) for both 2-MIB and GSM. Beside the report by Deng et al. [38], previous purgeand-trap methods reported [32-36] do not provide reproducibility precision data for either 2-MIB or GSM. However, our study shows that GSM can be quantitated with acceptable accuracy and precision. The observed sensitivity for both taste-odorants (LOQ $=1 \mathrm{ng} / \mathrm{L}$ ) is an improvement on that achieved by previous purge-trap methods [3538].

The optional water chiller, available as an accessory for the Stratum sample concentrator, was not included during the method development and validation [37]. The lower limits of quantitation and detection in the absence of salt [34] or methanol [37], achieved with the Eclipse, is proposed to be due to the enhanced stability brought about by the chilling of the water samples in the autosampler rack by the CARON circulator.

Although there is no apparent observation of the dehydration product of 2-MIB on the Stratum instrument, the day-to-day precision and sensitivity of the technique requires further investigation and optimization. The following variables require further study: addition of the sample chiller to the Stratum, to maintain the samples at $4^{\circ} \mathrm{C}$, use of the narrow bore GC inlet liner (previous work on the Stratum was based on the Supelco split liner) and elimination of the $1 \%(\mathrm{v} / \mathrm{v})$ methanol to the samples.

\section{Conclusion}

The developed test method, based on a solvent-free, salt-free purge- and-trap sample concentration, followed by GC-MS, has been shown to be sensitive, accurate, and precise over the linear range 5-100 ng/L for the trace analysis of geosmin in water matrices. From a general water quality perspective, the ultimate goal is to develop a test method that is sensitive, accurate and reproducible for the simultaneous analysis of both taste-odorants 2-MIB and GSM. Further method validation investigation on the Eclipse 4660 instrument will include the following parameters to optimize the day-to-day precision for 2-MIB: replicate runs at sample purge temperature of $30^{\circ} \mathrm{C}$, especially at $55^{\circ} \mathrm{C}[38]$ and higher, and the use of lower split ratios (e.g 2: 1, and even splitless) in order to offset the reduced sensitivity as a result of the lower sample purge temperature.

\section{Acknowledgements}

The authors acknowledge the assistance of Technical Supervisor Mr. T. Khumalo, Chemical Sciences, Scientific Services Laboratories, and Ms. M. September, in-service trainee student, Chemical Sciences, Scientific Services Laboratories, for assistance with some of the generation of the method validation data.

\section{References}

1. Mallevialle J, Suffet, IH (Eds.) (1987) Identification and treatment of tastes and Odors in Drinking Water, American Water Works Association and Lyonnaise des Eaux, American Water Works Association, Denver, CO.

2. Sung YH, Li TY, Huang SD (2005) Analysis of earthy and musty odors in wate samples by solid-phase micro extraction coupled with gas chromatography/ion trap mass spectrometry. Talanta 65: 518-524.

3. Watson SB, Brownlee B, Satchwell T, Hargesheimer EE (2000) Quantitative analysis of trace levels of geosmin and MIB in source and drinking water using headspace SPME. Water Res 34: 2818-2828.

4. Zhang L, Hu R, Yang Z (2006) Routine analysis of off-flavor compounds in water at sub-part-per-trillion level by large-volume injection GC/MS with programmable temperature vaporizing inlet. Water Res 40: 699-709.

5. Bao ML, Barbieri K, Burrini D, Griffini O, Pantani F (1998) Determination of trace levels of taste and odor compounds in water by microextraction and gas chromatography-ion-trap detection-mass spectrometry. Water Res 31: 17191727.

6. Shin HS, Ahn HS (2004) Simple, Rapid, and Sensitive Determination of odorous Compounds in Water by GC-MS. Chromatographia 59: 107-113.

7. Johnsen PB, Kuan JCW (1987) Simplified method to quantify geosmin and 2-methylisoborneo concentrations in water and microbiological cultures. J Chromatogr 409: 337-342.

8. Kim HJ, Kim K, Kim NS, Lee DS (2000) Determination of floral fragrances of Rosa hybrida using solid-phase trapping-solvent extraction and gas chromatography-mass spectrometry J Chromatogr 902: 389-404

9. Schellin M, Popp P (2006) Miniaturized membrane-assisted solvent extraction combined with gas chromatography/electron-capture detection applied to the analysis of volatile organic compounds. J Chromatogr 1103: 211-218.

10. Eaton AE, Clesceri AD, Rice EW, Greenberg AE (Ed.) (2005) Standard Methods for Examination of Water \& Waste Water 6040 Constituent concentration by gas extraction 6-8 to 6-22.

11. Ginzburg B, Chalifa I, Zohary T, Hadas O, Dor I, et al. (1998) Identification of oligosulfide odorous compounds and their source in the Lake of Galilee. Water Res 32: 1789-1800.

12. Malleret L, Bruchet A, Hennion MC (2001) Picogram Determination of "EarthyMusty" Odorous Compounds in Water Using Modified Closed Loop Stripping Analysis and Large V olume Injection GC/MS. Anal Chem 73: 14851490.

13. Yang MJ, Harms S, Luo YZ, Pawliszyn J (1994) Membrane Extraction with a Sorbent Interface for Capillary Gas chromatography. Anal Chem 66: 13391346

14. Zander AK, Pingert P (1997) Membrane-based extraction for detection of tastes and odors in water. Water Res 31: 301-309.

15. Conte ED, Conway SC, Miller DW, Perschbacher PW (1996) Determination 
Citation: Manickum T, John W (2012) Method Validation for the Trace Analysis of Geosmin and 2-Methylisoborneol in Water by "Salt-Free" Purgeand-Trap Sampling/GC-MS, Using the Eclipse 4660 Sample Concentrator. Hydrol Current Res 3:134. doi:10.4172/2157-7587.1000134

of methylisoborneol in channel catfish pond water by solid phase extraction followed by gas chromatography-mass spectrometry. Water Res 30: 21252127.

16. López R, Aznar M, Cacho J, Ferreira V ( 2002) Determination of minor and trace volatile compounds in wine by solid-phase extraction and gas chromatography with mass spectrometric detection. J Chromatogr A 966: 167-177.

17. Capriotti AL, Cavaliere C, Giansanti P, Gubbiotti R, Samperi R, et al. (2010) Recent developments in matrix solid-phase dispersion extraction. J Chromatogr A 1217: 2521-2532.

18. Caia L, Koziel JA, Neal MEO (2007) Determination of characteristic odorants from Harmonia axyridis beetles using in vivo solid-phase micro extraction and multidimensional gas chromatography-mass spectrometry-olfactometry. J Chromatogr A 1147: 66-78.

19. Saito K, Okamura K, Kataoka H (2008) Determination of musty odorants, 2-methylisoborneol and geosmin, in environmental water by headspace solid-phase micro extraction and gas chromatography-mass spectrometry. J Chromatogr A 1186: 434-437.

20. Kristiana I, HeitzA, Joll C, Sathasivan A(2010)Analysis of polysulfides in drinking water distribution systems using headspace solid-phase microextraction and gas chromatography-mass spectrometry. J Chromatogr A 1217: 5995-6001.

21. Fujise D, Tsuji K, Fukushima N, Kawai K, Harada K (2010) Analytical aspects of cyanobacterial volatile organic compounds for investigation of their production behavior. J Chromatogr A 1217: 6122-6125.

22. Xiaoyan MA, Naiyun G, Beibei C, Qingsong LI, Qiaoli Z, et al. (2007) Detection of geosmin and 2-methylisoborneol by liquid-liquid extraction-gas chromatograph-mass spectrum (LLE-GCMS) and solid phase extraction-gas chromatograph mass spectrum (SPE-GCMS). Front Environ Sci China 1: 286 291

23. Brownlee B, Macinnis G, Charlton M, Watson S, Hamilton-Browne S, et al. (2004) An analytical method for shipboard extraction of the odor compounds, 2-methylisoborneol and geosmin. Water Sci Technol 49: 121-127.

24. Shin HS, Ahn HS (2004) Simple, rapid and sensitive determination of odorous compounds in water by GC-MS. Chromatographia 59: 107-113.

25. Chang J, Biniakewitz R, Harkey G (2008) Determination of geosmin and 2-MIB in drinking water by SPME-PTV-GC-MS (2008) The Application Notebook.

26. Wang $H$ (2008) Analysis of geosmin and 2-methylisoborneol (MIB) by solid phase micro extraction (SPME) and Cl-MS-MS (2008) The Application Notebook.

27. Teledyne Instruments Application Notes. Analysis of musty odors in water using GC/MS-HT3 Teledyne Tekmar Dynamic Headspace.

28. Yoshimoto I, Honda S, Yamada N, Onuma S, Ban-ichi T, et al. (2003) Determination of geosmin and 2-methylisoborneol in water using solid phase extraction and headspace-GC/MS. J Mass Spectrom Soc Jpn 51: 174-178.

29. Nakamura S, Daishima S (2005) Simultaneous determination of 22 volatile organic compounds, methyl-tert-butyl ether, 1, 4-dioxane, 2-methylisoborneol, and geosmin in water by headspace solid phase microextraction-gas chromatography-mass spectrometry. Analytica Chimica Acta 548: 79-85.

30. Ligor M, Buszewski B (2006) An investigation of the formation of taste and odour contaminants in surface water using the headspace SPME-GC/MS method. (2006) Polish J of Environ Stud 15: 429-435.

31. Binkley J (2010) Analysis of taste odorants in drinking water by headspace-solid phase microextraction-gas chromatography-time of flight mass spectrometry. The Application Note.

32. Johnsen PB, Lloyd SW (1992) Influence of fat content on uptake and duration of the off-flavor 2-methylisoborneol by channel catfish (Ictalurus punctatus). Canadian Journal of Fish Aquatic Science 49: 2406-2411.

33. Lloyd SW, Lea JM, Zimba PV, Grimm CC (1998) Rapid analysis of geosmin and 2-methylisoborneol in water using solid phase micro extraction procedures. Water Res 32: 2140-2146.

34. Oceanography International Analytical Application Note 17350703 (2002) Geosmin and 2-methylisoborneol by Purge and Trap.

35. Salemi A, Lacorte S, Bagheri H, Barcelo D (2006) Automated trace determination of earthy-musty odorous compounds in water samples by on-line purge-andtrap-gas chromatography-mass spectrometry. J Chromatogr A 1136: 170-175.
36. Jurek A (2009) Analysis of geosmin and 2-methylisoborneol utilizing the Stratum PTC and Aquatek 70. Teledyne Tekmar. The Application Notebook.

37. Manickum T, John W, Malungana MP (2011) Trace analysis of taste-odor compounds in water by "salt-free" purge-and-trap sampling with GC-MS detection. Hydrol Current Res 2: 1-8.

38. Deng X, Liang G, Chen J, Qi M, Xie P (2011) Simultaneous determination of eight common odors in natural water body using automatic purge and trap coupled to gas chromatography with mass spectrometry. J Chromatogr A 1218 : 3791-3798.

39. Kristiana I, HeitzA, Joll C, Sathasivan A(2010)Analysis of polysulfides in drinking water distribution systems using headspace solid-phase microextraction and gas chromatography-mass spectrometry. J Chromatogr A 1217: 5995-6001.

40. Kolb B (1999) Headspace sampling with capillary columns. J Chromatogr A 842: 163-205.

41. Diaz A, Ventura F, Galceran MT (2005) Determination of odorous mixed chloro-bromoanisoles in water by solid-phase micro-extraction and gas chromatography-mass detection. J Chromatogr A 1064: 97-106.

42. Serrano E, Beltran J, Hernandez F (2009) Application of multiple headspacesolid-phase microextraction followed by gas chromatography-mass spectrometry to quantitative analysis of tomato aroma components. J Chromatog A 1216: 127-133.

43. Lara-Gonzaloa A, Sánchez-Uríaa JE, Segovia-García E, Sanz-Medel A (2008) Critical comparison of automated purge and trap and solid-phase microextraction for routine determination of volatile organic compounds in drinking waters by GC-MS. Talanta 74: 1455-1462.

44. Martin JF, Benner LW, Graham WH (1988) Off-flavor in the Channel catfish (Ictalurus punctatas) due to 2-methylisoborneol and its dehydration products. Water Sci Technol 20: 99-105.

45. Manickum T, John W (2012) Dehydration of 2-methylisoborneol to 2-methyl2-bornene in the trace analysis of taste-odorants in water by purge-and-trap sampling with gas chromatography-mass spectrometry. Hydrol Current Res 3 : $1-19$

46. Umgeni Water, SANAS Drive (P), Manuals, Procedure Manual, SOP $16 \mathrm{~b}$ Method Validation (Chemical Sciences). 12/08/2010, Ed02/Rev03.

47. The Fitness for Purpose of Analytical methods. A Laboratory Guide to Method Validation and Related Topics. First English Edition 1.0.1998. ISBN: 0-94892612-0.

48. Deng X (2012) Personal Communication. 02/05/2012. 